Aleksandar R. Radosavljević

Scientific Associate

Mechanical Engineering Department The Institute of Transportation CIP Belgrade

Vojkan J. Lučanin

Full Professor

University of Belgrade

Faculty of Mechanical Engineering

Bernhard Rüger

Researcher

Vienna University of Technology

Research Center for Railway Engineering,

Traffic Economics and Ropeways

Austria

Snežana D. Golubović

Researcher

University of Belgrade

Faculty of Mechanical Engineering

\section{Rolling Stock Doorways Compatibility with Platforms at Serbian Railways}

This paper shows some of the passenger difficulties when boarding trains. Overview of platform heights is discussed in accordance with international railway regulation. An overview of platform heights at Serbian railway lines and floor heights of passenger coaches, diesel units and electric multiple units for suburban and regional railway transport are shown. This paper is focused on the differences between procurement policy, regarding doorway compatibility with platforms, of diesel and electric multiple units for Serbian Railways and consequences of these acquisitions.

Keywords: railway, platform height, vehicle accessibility, diesel multiple units, electric multiple units.

\section{INTRODUCTION}

Over the years different types of rolling stock have been introduced and platforms constructed to different heights. A large number of passengers, especially persons with reduced mobility (PRM) [1], have problems when boarding a train. PRM are all people who have difficulty when using trains or the associated infrastructure. The following categories of PRM include: wheelchair users, people with limb impairment, people with ambulant difficulties, people with children, people with heavy or bulky luggage, elderly people, pregnant women, visually impaired or blind people, hearing impaired or deaf people, communication impaired persons and people of small structure. This means that the stepping distance between platform edge and train coaches can vary at some stations around the network.

Beside the problems passengers can encounter, the operators can have difficulties with bad boarding situations because of the longer dwelling time.

This paper will focus on height differences, in some cases, between the platform and the vehicle floor regarding Serbian Railways (ŽS) network and rolling stock.

At $\check{Z} S$ there is a significant discrepancy between the rolling stock and the existing height of the platform, so it is necessary to perform a detailed analysis of individual relations of traffic and take measures to harmonize the system. Also, when purchasing new vehicles it is necessary to clearly define where the new vehicles will operate, and consequently perform synchronization between the platform and the vehicle.

\section{BOARDING SITUATIONS}

Regarding the question of what difficulties passengers

Received: June 2015, Accepted: May 2016

Correspondence to: Dr Aleksandar Radosavljević

The Institute of Transportation CIP Belgrade,

Nemanjina 6, 11000 Belgrade, Serbia

E-mail: radosavljevica@ sicip.co.rs

doi:10.5937/fmet1701077R

(C) Faculty of Mechanical Engineering, Belgrade. All rights reserved have when boarding a train in different boarding situations - different vehicles combined with different platforms - can be categorised as follows [2]:

- Level Boarding, one stair step max.: travellers of all ages, with or without luggage, rarely have difficulties.

- Access with two stairs, wide doors, and stairs with flat angles: travellers with luggage, regardless of age, rarely have difficulties when accessing the vehicle.

- Access with RIC (The International Coach Regulations) wagons and related trains (three stairs from platform): between $10-15 \%$ of travellers have difficulties or a lot of difficulties when accessing the train without luggage and $25-30 \%$ with luggage.

- Old-type vehicles, steep stairs (3-4 stairs from platform): $20-30 \%$ of travellers do have difficulties and severe difficulties with stairs and $50 \%$ of travellers with luggage. Approximately $20 \%$ of travellers with luggage do need foreign assistance. Approximately $8 \%$ amongst the group of 40 to 59 year old, and approximately $20 \%$ amongst the group of over 60 year-old, require personal assistance when accessing the vehicle.

The survey $[2,3]$ clearly shows that the great part of the travellers have no problem when using an access with no step or even one step. When two steps are to be passed in combination with luggage the difficulties grow rapidly. Especially elderly and small children have got big problems when they have to pass a vertical gap of about more than $250 \mathrm{~mm}$. Fig. 1 shows a step high of about $400 \mathrm{~mm}$ and the difficulty people of small structure or elderly passengers have.

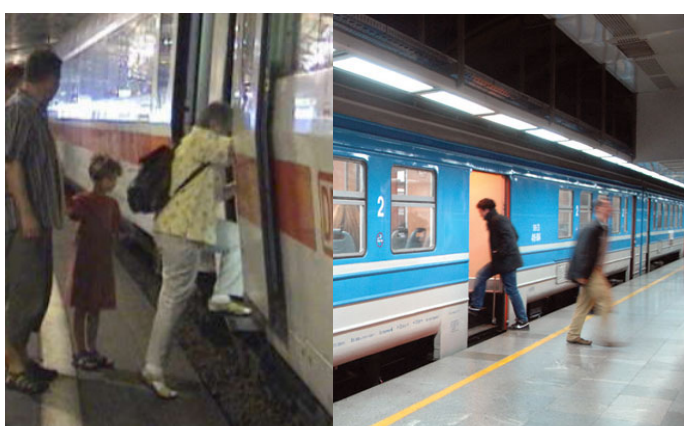

Figure 1. Difficulties with a large vertical gap 


\section{REGULATIONS GOVERNING THE POSITIONING OF PLATFORM IN RELATION TO THE TRACK}

Fig. 2 shows many different platform heights (combined with the UIC (International Union of Railways) clearance diagram) that exist in Europe $[4,5]$. The EUstandard is $550 \mathrm{~mm}$ and $760 \mathrm{~mm}$ above the running surface, for platforms on the Conventional Rail Network, depending on the type of rolling stock that may be stopped at the given platform. Under certain conditions different height may be used:

- greater than $760 \mathrm{~mm}$ - so called high platforms dedicated exclusively for commuter trains specially designed for the given platform height (typically 960 $\mathrm{mm}$ ) in order to ensure one level access and possibility of increasing number of doorways on each side of every coach,

- smaller than $550 \mathrm{~mm}$ - so called low platforms - for different but not all types of trains - in order to fulfill particular architectural or operational requirements (some old fashioned stations, border stations, small local stations with passages located along the usefull length of the platform edges); in such cases however the minimal height of upgraded platform edge shall be $380 \mathrm{~mm}$ [4].

. $150 \mathrm{~mm}$
$.250 \mathrm{~mm}$
$.300 \mathrm{~mm}$
$.380 \mathrm{~mm}$
$.550 \mathrm{~mm}$ (EU-Standard)
. $760 \mathrm{~mm}$ (EU-Standard)
$.840 \mathrm{~mm}$ (NL)
. $915 \mathrm{~mm}$ (GB)
. $960 \mathrm{~mm}$
. others

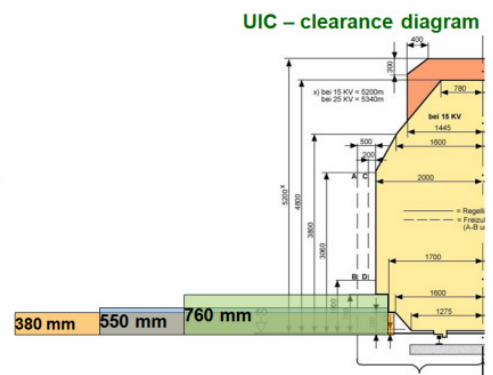

Figure 2. Variety of typical platform high in Europe

Both heights i.e. $550 \mathrm{~mm}$ and $760 \mathrm{~mm}$ ensure compatibility with coaches of $\mathrm{Y}$ and $\mathrm{Z}$ standard having a floor height at $1255 \mathrm{~mm}$ level and four-step access [6, 7] giving the smallest possible:

- horizontal gap at $550 \mathrm{~mm}$ height platform,

- vertical distance to cover from $760 \mathrm{~mm}$ platform.

The distance between coach steps (step height) should be approximately $230 \mathrm{~mm}$. On standard coaches the maximum distance between steps must be $270 \mathrm{~mm}$ maximum [8].

Many new vehicles - especially for local traffic have got a vehicle floor about $600 \mathrm{~mm}$ high. So this situation allows level boarding. Also double decker trains offer level boarding over these platforms. They can also be used for long distance InterCity-traffic. Platform height of $760 \mathrm{~mm}$ is typical for high speed trains. So, usually only two steps remain. Some high speed trains have got a lower vehicle floor, like TGV or Spanish Talgo-trains. Here passengers only have to pass one step to get on from level boarding.

For train operation the boarding time is a very important criterion of quality. The boarding and alighting time has a strong influence on the dwell time and so on the timetable and the punctuality. But in the whole system the platform height influences the time needed because lower platforms mean a larger vertical gap. In general we can say that level boarding is the optimum that can be reached with $550 \mathrm{~mm}$ high platforms and today's vehicles. One remaining step is also good for most passengers. Two steps are the limit that can be accepted, but only if we have doors wider than $800 \mathrm{~mm}$, so at least $900 \mathrm{~mm}$. More than two steps is a very poor solution. In accordance to [4] following situations are suggested:

- Urban and suburban trains should have no level difference between platforms and vestibules or maximum one step for accessing the train. The maximum of two steps is allowed when trains are in service out of suburban areas.

- Regional trains should be accessed from platforms with equal height as the vestibules or over one step. Not more than two steps can be considered acceptable for passengers.

- Intercity, inter-regional and high speed trains should not have more than three steps for accessing trains from station platforms.

It should be noted that the UIC regulations is not defined by the distance between the edge of the platform and the vehicle, but some of railway administration brought its internal regulations that apply only to a particular type of traffic. Also, strategic aim to minimize the horizontal gap between edge and first usable step must be achieved .

\section{POSITION OF COMPANY ,SERBIAN RAILWAYS”}

\subsection{Platform heights}

Serbian electrified railway lines together with lines planned for electrification in near future have 276 service points from which 111 have no platforms at all. Four stations are with high platforms $\mathrm{H}$ (height above the running surface, perpendicular to it) $=960 \mathrm{~mm}, 13$ have platforms of intermediate heights $(350 \mathrm{~mm}<\mathrm{H}<$ $550 \mathrm{~mm})$ and the remaining are with low $(300 \mathrm{~mm}<\mathrm{H}$ $<350 \mathrm{~mm}$ ) platforms or have no platforms at all. All four stations with high platforms (Rakovica, Vukov Spomenik, Pancevacki Most and Zemun) are in the Belgrade Railway Junction (Fig. 3). Only one track in Zemun station was equipped with a platform last year, with a platform height $\mathrm{H}=550 \mathrm{~mm}$. ŽS plan is to make reconstruction of all platforms to the height $\mathrm{H}=550 \mathrm{~mm}$, in the process of railway network modernization,.

When taken into consideration the diesel multiple units (DMU) service on non-electrified lines 130 service points have no platforms at all. Further, 166 service points have platforms of top of rail height, 111 have low platforms $(300 \mathrm{~mm}<\mathrm{H}<350 \mathrm{~mm})$ and only three have intermediate heights $(350 \mathrm{~mm}<\mathrm{H}<550 \mathrm{~mm})$. Still, there are no plans for uniform platform height on non-electrified lines.

\subsection{The existing and new rolling stock heights}

Serbian Railways mostly purchased single floor ( $\mathrm{Y}$ and $\mathrm{Z})$ passenger coaches with $1255 \mathrm{~mm}$ floor height above the running surface which is in concordance with UIC regulations for wheel diameters of $920 \mathrm{~mm}$. Each entrance door has three steps which allow boarding over four stepping points (Table 1, Fig. 4). 


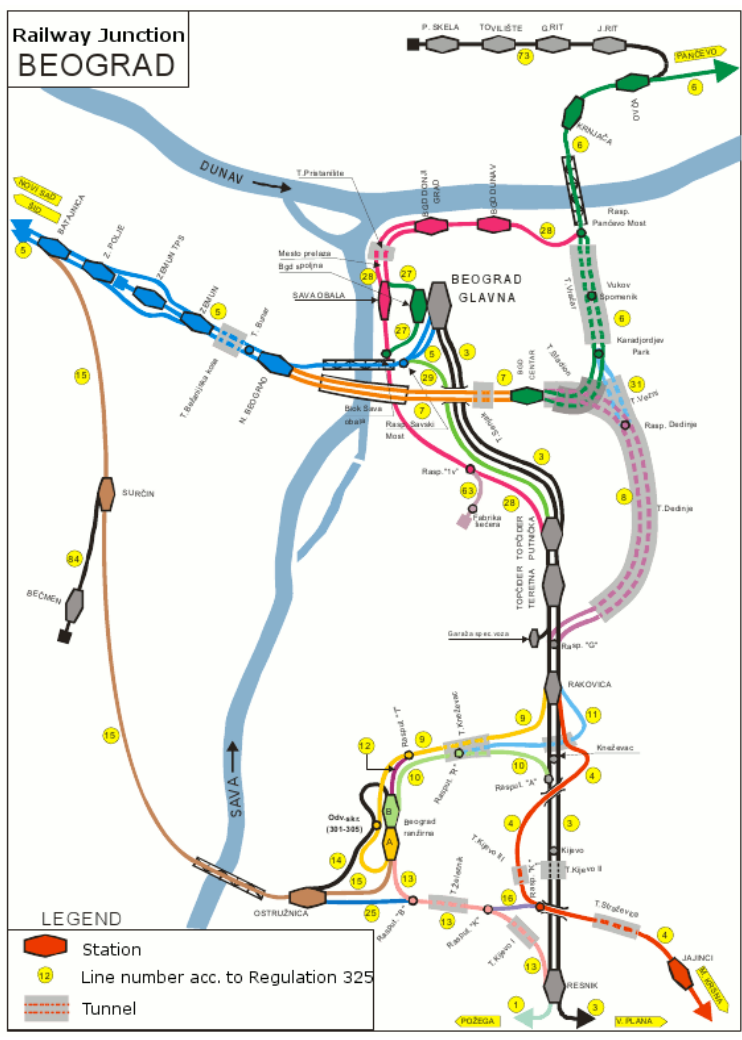

Figure 3. Belgrade Railway Junction scheme

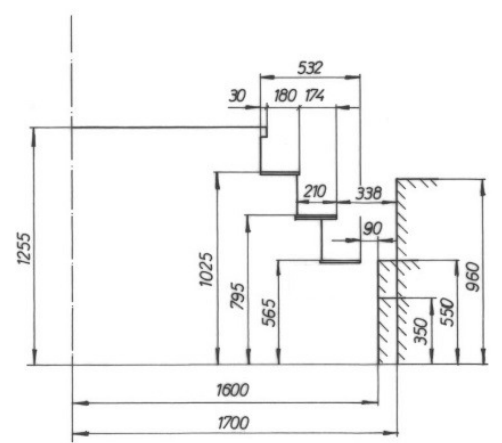

Figure 4. Passenger car doorway

The footboard of the bottom step of the entrance is 565 $\mathrm{mm}$ above the running surface and the fourth footboard has the same height as the coach floor. The depth of the steps is $210 \mathrm{~mm}$ and the step height is $230 \mathrm{~mm}$.

This entrance is suitable for the station platform height of $550 \mathrm{~mm}$ and low platforms, although when passengers leaving the platform height of $350 \mathrm{~mm}$ stairs are very steep and uncomfortable. At the high platform height of $960 \mathrm{~mm}$ the large distance between the edge of coach and the platform edge $(338 \mathrm{~mm})$, as well as the unpleasant step up creating an uncomfortable

Table 1. Žs rolling stock characteristics

\begin{tabular}{|l|l|l|c|c|c|c|}
\hline \multicolumn{1}{|c|}{ Rolling stock } & \multicolumn{1}{|c|}{ Manufacturer } & \multicolumn{1}{|c|}{$\begin{array}{c}\text { Year of } \\
\text { production }\end{array}$} & $\begin{array}{c}\text { Active } \\
\text { inventory } \\
\text { park }\end{array}$ & $\begin{array}{c}\text { Height of floor } \\
\text { above the top of } \\
\text { rail [mm] }\end{array}$ & $\begin{array}{c}\text { Height of the first } \\
\text { step above the top } \\
\text { of rail [mm] }\end{array}$ & $\begin{array}{c}\text { Maximum car } \\
\text { body width } \\
{[\mathrm{mm}]}\end{array}$ \\
\hline Passenger car Y,Z & & $1966-1996$ & 305 & 1255 & $600 / 565$ & 2825 \\
\hline EMU 412/416 & RVZ - Riga & $1980-1998$ & 25 & 1385 & 591 & 2810 \\
\hline EMU Flirt3 413/417 & Stadler & 2014 & 21 & 600 & 570 & 2820 \\
\hline DMU 710 & FAT & $1979-1980$ & 10 & 1230 & 610 & 2878 \\
\hline DMU 711 & Metrowagonmash & 2011 & 12 & 1290 & 560 & 2934 \\
\hline DMU 712/714 & MACOSA & 1980 & 12 & 1169 & 595 & 2850 \\
\hline DMU 812/814/818 & GOŠA & $1958-1969$ & 22 & 1440 & 600 & 3000 \\
\hline
\end{tabular}

impression on travellers. Practically this entrance fits the platform height of $550 \mathrm{~mm}$ best.

Electric multiple unit (EMU) series 412/416 is train for urban and suburban transport on network of ŽS. Floor height is $1385 \mathrm{~mm}$ above the running surface (Fig. $5)$. Vestibule area has three steps and the lowest is on $591 \mathrm{~mm}$ resulting in difficulties when boarding in stations with no platforms or with low platforms. Train width is just $2810 \mathrm{~mm}$ which creates boarding and alighting problems even on high platforms because of the large gap between the platform edge and the vehicle. The car body width is $2810 \mathrm{~mm}$ and a problem arises with high platforms because there is a big gap between makes it difficult for passengers entering and exiting.

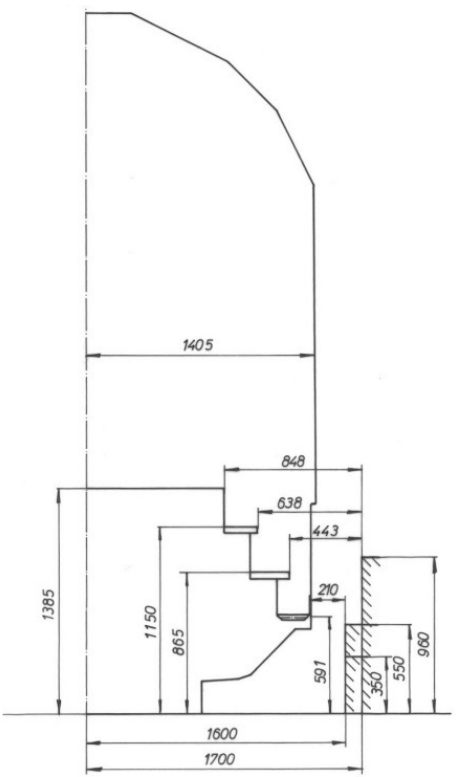

Figure 5. EMU 412/416 doorway

Practically doorways of electric train series 412/416 fit only the height of the platforms 550 and $350 \mathrm{~mm}$, while for the high platforms and the stations without platforms they are completely inappropriate.

Diesel multiple unit (DMU) series 711 has vestibules with two upper steps which are fixed and two lower movable steps (Fig. 6). The upper movable step positioning is in connection with door opening. Its height is $560 \mathrm{~mm}$ above the running surface. Only in stations with low platforms and with no platforms at all every single fourth lower movable step is activated separately by electro-pneumatic devices designed for it. The height of the lowest step is $380 \mathrm{~mm}$ above the running surface. the vehicle and the platform edge $(295 \mathrm{~mm})$, which 


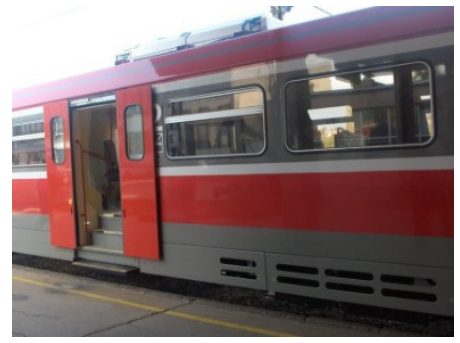

Figure 6. DMU 711 doorway

DMUs series 710, 712/714 and 812/814/818 are outdated vehicles with high level of floor height due to the underfloor position of diesel engine (Fig. 7, 8, 9).

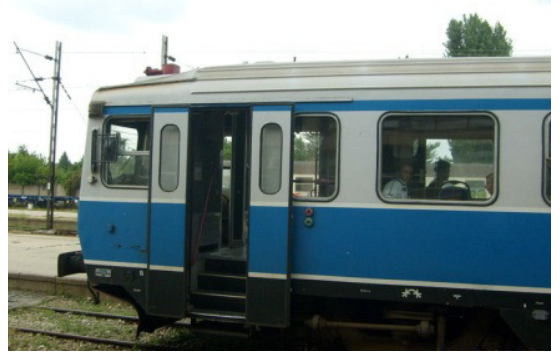

Figure 7. DMU 710 doorway

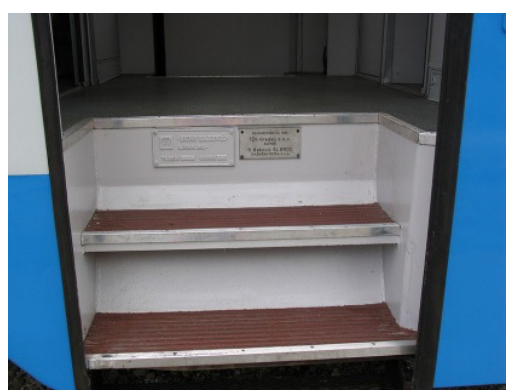

Figure 8. DMU 712 doorway

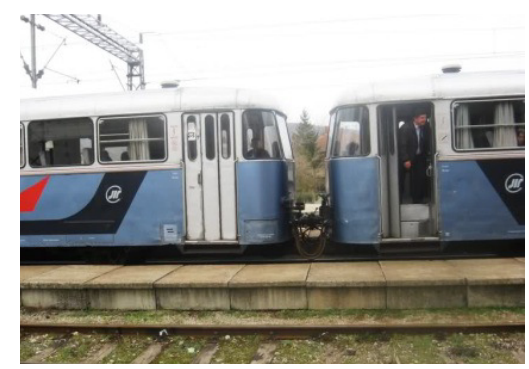

Figure 9. DMU 812/814/818 doorway

The new ŽS EMU 413/417 have one double door for entering and exit of passengers on each side of each car. Height of the floor at the entrance area is $600 \mathrm{~mm}$. All entrances of the vehicles are situated in the low floor sections. Entrance and exit are easily and safely accessible from platform heights of $550 \mathrm{~mm}$ and 350 mm (Fig. 10). A system with sliding steps ensures boarding without step from the $550 \mathrm{~mm}$ platform as well as comfortable ascending even from low platform heights as $350 \mathrm{~mm}$. To enter from the lower platforms with $350 \mathrm{~mm}$ height the sliding step acts as a step that provides a maximum step height of less than $230 \mathrm{~mm}$ according to Technical Specification for Interoperability - Accessibility for Persons with Reduced Mobility (TSI PRM).

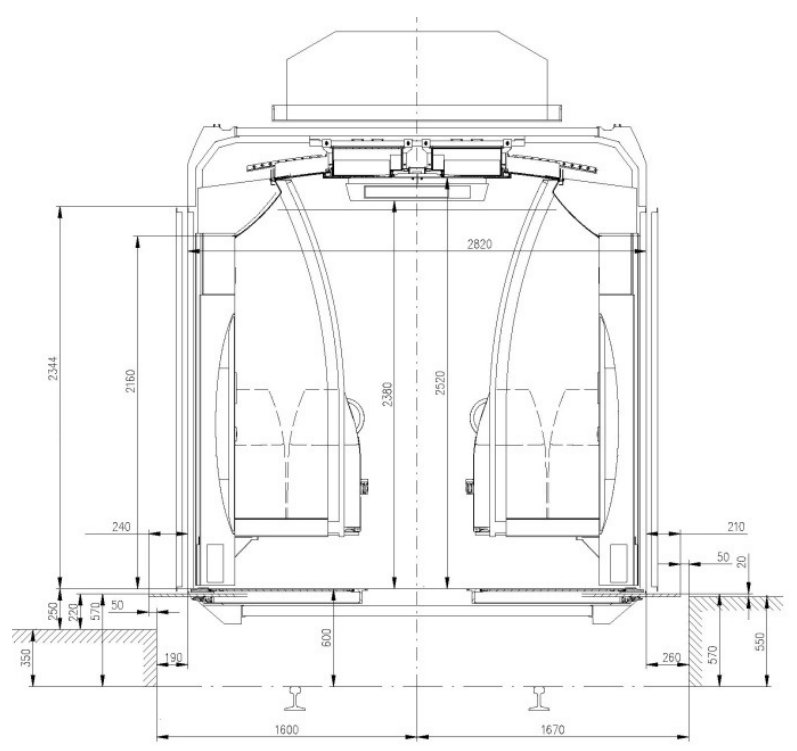

Figure 10. EMU Flirt3 $413 / 417$ cross-section and platforms

\subsection{The internal regulation}

The choice of platform heights on ŽS network and purchasing of new rolling stock should take existing vehicles and platforms into consideration together with the intention of minimizing gaps between platforms and first door step. Furthermore, it is necessary to minimize the number of steps between platforms and vestibule [9].

Based upon analysis of rolling stock and platforms on network ŽS internal Commission for Platforms decided that new EMU/DMU should allow easy boarding and alighting of trains for passengers over the first step:

- At a height of $550 \mathrm{~mm}$ (equal to medium platform height) for EMUs in regional service and

- At a height of $350 \mathrm{~mm}$ for DMUs in regional and local service (at low platform height).

\section{CONCLUSION}

The best boarding situation that can be offered to the passengers is level boarding. All passengers benefit from this situation - passengers with reduced mobility as walking disabled, elderly but also passengers with luggage or baby prams. Level boarding is not only the most comfortable access for passengers but also the best and most time efficient situation for the operators. Passengers need approximately double the time when boarding a high floor vehicle compared to level boarding. The worst situation is to have platforms lower than $250 \mathrm{~mm}$ so that the first step is more than $300 \mathrm{~mm}$. Here the influence is even worse.

Quite similar to level boarding is boarding over one step if it is not higher than $250 \mathrm{~mm}$. This situation can be handled by the most passengers without any difficulties. Also the time needed is very similar to level boarding.

Having two steps at maximum height difference of about $500 \mathrm{~mm}$ is the worst combination that should be 
allowed. Passengers passing over more than two steps generally have many difficulties. When having two steps in passenger exchange it is very favourable to have a door width of at least $900 \mathrm{~mm}$.

The entrance of passenger coaches best fit a platform height of $550 \mathrm{~mm}$.

Old-type DMUs are completely inadequate for service on non-electrified Serbian railway lines, but because of their age can still operate until the end of its life cycle. New vehicles must be purchased with maximum floor height of $600 \mathrm{~mm}$.

For all passengers, especially persons with reduced mobility, one of the most off-putting features of the new Metrowagonmash DMU series 711 is the floor height. The DMUs were designed with the high station platforms common in Russia in mind, neglectful of the fact that many stations and stops (as in Serbia) still have very low platforms or no platforms at all. On account of the exceptionally high floor of the units a flight of four steps is provided for use at low platforms (for service points with no platforms at all or with platforms of top of rail height even five steps!). These trains are inadequate for service on non-electrified Serbian railway lines and all the more surprising is the fact that ŽS did notask in Technical specifications for procurement, that maximum floor height of new DMUs be $600 \mathrm{~mm}$.

ŽS EMU 412/416 creates boarding and alighting problems even on high platforms because of the large gap between the platform edge and the vehicle. Practically, entrance in electric train 412/416 fits only the height of the platform, 550 and $350 \mathrm{~mm}$, while in the case of high platforms and the stations without platforms it is completely inappropriate.

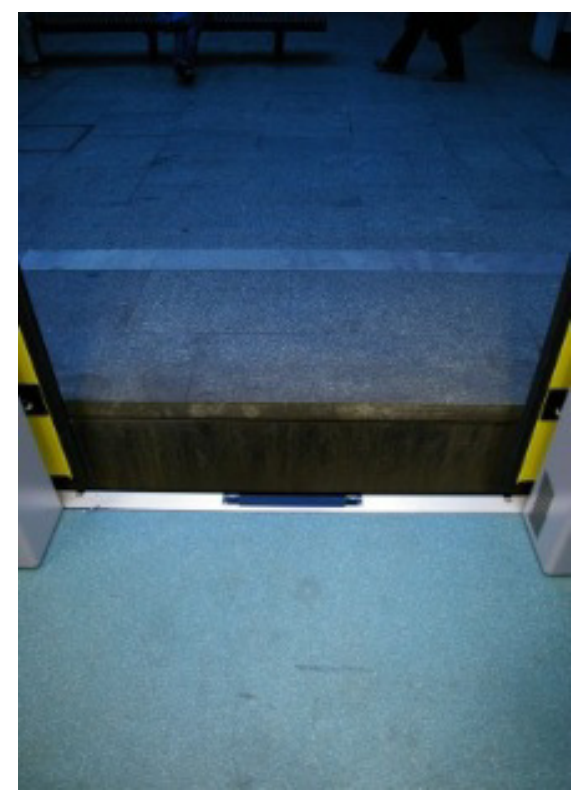

Figure 11. One additional step

If, in the process of railway network modernization, ŽS do not do reconstruction of all platforms to the height $\mathrm{H}=550 \mathrm{~mm}$ above the running surface, the problems will rise in stations with platform height of $960 \mathrm{~mm}$. In these cases one unpleasant step of $360 \mathrm{~mm}$, during exit from new Stadler EMU 413/417 floor to platform, will appear. Fig. 11 shows relation between
EMU floor and platform height of $960 \mathrm{~mm}$ in Warsaw [10]. Also, in this case, the entrance door height will be $360 \mathrm{~mm}$ less which can lead to problems when passengers entering the vehicle (the clearance of the opened door is $1300 \mathrm{~mm}$ horizontally and $2100 \mathrm{~mm}$ vertically).

Finally, this paper shows differences between procurement policy of diesel and electric units for Serbian Railways, according to vehicle floor height, and consequences of these acquisitions. Unfortunately, the consequences cannot be eliminated by investment in rolling stock, but only in infrastructure, which is a long and expensive process $[11,12]$.

\section{REFERENCES}

[1] The technical specification of interoperability relating to 'persons with reduced mobility' in the transEuropean conventional and high-speed rail system, Official Journal of the European Union, 2007.

[2] Radosavljević, A., Rüger, B. and Mirković, S., Passenger Behaviour in Boarding Situations and Relation Between Platform Height and Rolling Stock Floor Height, in: XIV Scientific-expert conference on railways RAILCON '10, October 2010, Niš, pp. 21-24.

[3] Rüger B, Tauschitz P, Petutschnig B., Boarding Assistance System Evaluation Criteria Report, deliverable 2.1, June 2010. EU-FP7-Project Public Transportation - Accessibility for all.

[4] UIC 741, Passenger stations - Height of platforms Regulations governing the positioning of platform edges in relation to the track, 2007.

[5] Wieder, H-F., Kollmann, M., Accessibility Vehicle Manufacturer's Requirements, Engineering Metros \& Coaches, in: Conference Public Transport-Accessibility for All, May 2010, Vienna.

[6] UIC 567-1, Standard X and Y coaches accepted for running on international services, 4 th edition of 1.1.78 and 7 Amendments.

[7] UIC 567-2, Standard Z-type coaches accepted for running in international traffic - Characteristics, 4th edition of 1.7.91 and 2 Amendments.

[8] UIC 560, Doors, footboards, windows, steps, handles and handrails of coaches and luggage vans, 12th edition, March 2002.

[9] ŽS, Report of the commission for determining platforms height and width at the Serbian railway lines, (Izveštaj komisije za određivanje visine $\mathrm{i}$ širine perona na prugama ŽS), (in Serbian), Belgrade, 2009.

[10] http://www.skyscrapercity.com/showthread.php?p= 26180004

[11]Popović, Z., Puzavac, L. and Lazarević, L., Improving the accessibility of passenger railways in the Republic of Serbia, RTR - Rail Technology Review, 2/2012, pp. 25-29,

[12] Popović, Z., Stevanović, K. and Puzavac, L., Railway Terminals - Accessibility for Persons with Reduced Mobility, SPATIUM International Review, No. 20, September 2009, pp.60-67. 
перона према међународним железничким прописима.

КОМПАТИБИЛНОСТ ВИСИНЕ ПОДА

ШИНСКИХ ВОЗИЛА И ВИСИНЕ ПЕРОНА НА ПРУГАМА ЖЕЛЕЗНИЦЕ СРБИЈЕ

\section{А. Радосављевић, В. Лучанин, Б. Ригер, С. Голубовић}

Рад приказује неке потешкоће које имају путници при уласку у воз. Приказане су и размотрене висине
Дат је преглед висине перона на српским пругама и висине пода путничких кола, дизел и електричних вишеделних јединица за приградски и регионални саобраћај. Рад се фокусира на разликама између политике набавке, у односу на компатибилност улазишта са перонима, дизел и електричних вишеделних јединица Железнице Србије и последицама ових набавки. 